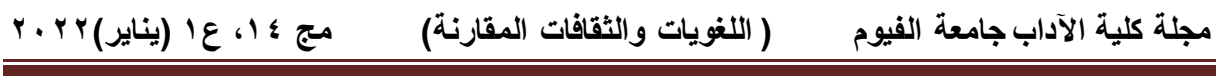

\title{
"Aladdin" in the Eyes of Disney 2019: Reflections on Cultural Representation of Middle East Identity
}

\author{
Yousreya Ahmed Alhamshary* \\ alhamshary@edu.dmu.edu.eg
}

\section{Abstract}

Disney animated films play an important role in presenting and modifying values via adaptable characters for all world's children or even adults. These films reduce the gab of viewers' different cultures and social values and represent a good source of imagination and love. The old romantic story of Aladdin lives in most children's minds and hearts till now, used to highlight the eastern cultural identity in the current film and the change of Arabian cultural discourse. The study aims at identifying different cultural aspects, values, and the shift of Disney's visualization of the Arabian identity. Kress and Van Leeuwen and Fairclough are used as theoretical frameworks to analyze the discourse of the film. Results indicate a noticeable change in Disney's views about the Arabian identity with continuous bias to the power of American culture and a final focus on the Arabian values. Consequently, more studies are recommended to be conducted about the film and its different effects on different sides of both societies. More deep analysis is required to get cultures closer and more understanding toward each other.

Keywords: Identity, cultural ideologies, text and image, Disney

films

\footnotetext{
Associate prof. of linguistics, Faculty of Education, Damanhour University.
}

("Aladdin" in the Eyes of Disney 2019...) Dr. Yousreya Ahmed Alhamshary 


\section{Introduction}

Recently, visual communication with colors and shapes is believed to have a "psychological," direct, and unmediated impact on viewers. Further, it is removed from the sphere of art, to become part of the more powerful and public sphere of industrial production. Walt Disney Company have produced many remarkable animated films over decades, featured with songs composed only for them, which have especially central idea that increases the popularity of these films (Hischak \& Robinson, 2009). These songs play significant roles in storytelling and help audiences understand the discourse and characters' emotions and feelings within the context (Edmondson, 2013).

Recent technology has the great impact on children who live in a society where the Internet, television, video games, and movies are natural parts of their daily life and environment. They are influenced by television and movies, especially those produced by Disney (Berry 2003). Children's characters are shaped by their attitudes and impressions from their surroundings, and they considerably establish perception of their values from books, movies, and television as expressed by Witt (2000); therefore, comes the significance of these films in every social context and family life.

The new version of Aladdin (2019) makes changes to peoples' life because of messages included to the whole world. The new version of Aladdin is addressing culture awareness to fill the gap between the American society and other countries seen within the hatred and malice for the Americans through the $11^{\text {th }}$ of September. The style of communication changed by the progress of mass media addressing cultural side too as illustrated by Kellner and Durham (2001). This means that both Disney and American people's ideology and strategy of addressing other

("Aladdin" in the Eyes of Disney 2019...) Dr. Yousreya Ahmed Alhamshary 
countries or other audience markets need to be reviewed and reformulated to fit the new era.

Based on the characteristics and concept of culture mentioned here in this research, in addition to change of communication mode, Disney reconstructed its way of communication with the whole world. For Hudson (1980), culture is shared knowledge which is relevant to language that is learned by people, and at the same time culture is based on and integrated on symbols. When dealing with the other, there are three kinds of knowledge that should be considered: (1) cultural knowledge: it is learned from other people. That is why most animated films dealt with model life and values. (2) Shared non-cultural knowledge: it is shared by people within the same community but is not learned from others, which resulted in Disney films addressing most types of communities in the world. (3) Non-shared cultural knowledge: it is restricted to a specific community and is hidden in deep personalities. Disney world is one of the institutions that already addresses these types of knowledge about culture, dealing with the whole world and having such a reputable position in the world of media.

\section{Aims and Methodology}

Fairclough's (1989) theoretical framework is used to analyze the following selected text. First level of analysis focuses on the language practice and some expressions by the main characters in the film. In this part, the focus is on the linguistic devices such as metaphor, specific words, diction, repeated words, and naming in general. The second level deals with the discourse practices which cover the intertextuality of ideas, concepts that show the consumption and production of the text. The third level interprets the social practice done by persons in exercising their power. Then, some screenshots are selected from the film about the characters' activities and ideologies where Kress and Van

("Aladdin" in the Eyes of Disney 2019...) Dr. Yousreya Ahmed Alhamshary 
Leeuwen's theoretical framework is used to identify embedded messages.

Three dimensions are considered in picture analysis: the first is the social distance, the second is the social relation, and finally the third is the social interaction between depicted people and the viewer (Leeuwen, 2005, p. 138). Besides, more analysis on how picture depicts people is obtained from the aspects of "exclusion, roles, individual/group, and categorization" (Leeuwen, 2005, pp. 147-8). Furthermore, the role of a person in the picture shows how someone is depicted in specific or generic (ethnic) category or represented as an individual or part of a group. A picture of an individual represents a strong and clear identity about them, while a picture of individuals in a group tends to blur the individual identity. However, the group identity is highlighted more than the individual one.

\section{Theoretical Background}

Alf laylah wa-laylah is folktales book about a collection of west and South Asian stories compiled in Arabic known as the Arabian Nights, written during the Islamic Golden Age. "Aladdin" as a story is a famous part of the Arabian Nights that is popular in western countries and was translated into many languages. A new version of the film is released in 2019 by Walt Disney Pictures earning over $\$ 750$ million as reported in (boxofficemojo.com) 2020.

Films are not merely for entertainment, but they are widely accepted by people and used to reflect and address important problems people face in history and to hold new messages to the audience (Miles, 1996, p. x). Martin and Ostwalt (1995, p. vii) point out that this film has potency of strengthening, challenging, and crystalizing a particular perspective of ideological assumption, religion, cultural aspects, norms, and values of different societies. They refer to the point that the cultural

("Aladdin" in the Eyes of Disney 2019...) Dr. Yousreya Ahmed Alhamshary 
products of it are a product of secular significances that effectively define the realities in consumer society. Long tradition of American Hollywood cinema is producing and strengthening emotion, cohesion, and imitation, reflecting its relation to the east culture (Miles, 1996, p. 3). However, in the 2019 version of the film, the impact of the east culture on the Arabian society is highly reflected. The construct of the Orient identity represented in Hollywood films is related to the colonial imagination of Hollywood and the evolution of western male gaze (Shohat, 1990, pp. 40-42). This view contributes to the analysis of how the film reflects people in different ethnicities, specifically people of the third-world countries (Arabian and eastern nations). Consequently, one of the devices to project US foreign policy is films or media. In Disney films, if a particular nation is an enemy, it is represented as a bad guy with features in opposition to American features. In contrast, allied countries are represented as good friendly guys (Totman, 2009, pp. 1-2). Hollywood films play the intended roles and become part of American social political power in the international context (Gardels \& Medavoy, 2009, p. 61).

The word culture is a very wide expression. Many scholars try to give accurate definition like that of Avruch (1998, pp. 6-17) "as a complex whole which includes knowledge, belief, art, morals, law, custom, and any other capabilities and habits acquired by man as a member of society." Another definition introduced by Adler (1997, p. 14) as "patterns, explicit and implicit, of and for behaviour acquired and transmitted by symbols, constituting the distinctive achievements of human groups, including their embodiment in artifacts. The essential core of culture consists of traditional ideas and especially their attached values; culture systems." Or "Culture is the collective programming of the mind which distinguishes the members of

(“Aladdin" in the Eyes of Disney 2019...) Dr. Yousreya Ahmed Alhamshary 
one group or category of people from another" as defined by Hofstede (2001, p. 5). However, Matsumoto (1996, p. 16) holds it is "the set of attitudes, values, beliefs, and behaviors shared by a group of people, but different for each individual, communicated from one generation to the next." For Spencer-Oatey (2008, p. 3), "Culture is a fuzzy set of basic assumptions and values, orientations to life, beliefs, policies, procedures and behavioral conventions that are shared by a group of people." All previous definitions of culture indicate the importance of considering communication among people and how people can affect and be affected by others. All definitions include behaviors and beliefs as components of culture. Films allow all types of cultures-internal or external-to get closer which certainly affects the formulation of the individual personality and in turn an identity of the community or society of that person. The human ability to feel fear, anger, love, joy, and sadness; the need to associate with others and to play and exercise oneself; and the facility to observe the environment and talk about it with other humans all belong to mental knowledge formation. However, what one does with these feelings and how one expresses fear, joy, observations, and so on are modified by culture.

For an idea, a thing, or a behavior to be considered cultural, it must be shared by some type of social group or society. Culture is transformed within people by one's interacting and communicating with them. Because there is a specific interest in the relationship between culture and interpersonal communication, scholars focus on how cultures provide their members with a set of interpretations that they use as filters to make sense of messages and experiences (Lustig \& Koester, 1999 , p. 2-31). Culture is not the same as identity which is based on mutual images and stereotypes, emotions, or values (Hofstede 2001, p. 10). Culture is both an individual construct and a social

(“Aladdin" in the Eyes of Disney 2019...) Dr. Yousreya Ahmed Alhamshary 
construct. Parallel to culture comes the ideology which is a set of opinions or beliefs of a group or an individual. Very often, an ideology refers to a set of political beliefs or a set of ideas that characterize a particular culture.

Recently, there has been numerous studies conducted to investigate the specific messages delivered through films and music genres, due to the power that the media hold regarding influencing individuals' especially children's understanding of society and other cultures. Mass media's extensive reach that nearly became impossible for the public to avoid has affected people's perceptions and understanding of many different cultural and social issues. Therefore, mass media provide a direct social understanding of the public and suggest what the collective societal beliefs should be (Hazell \& Clarke, 2008). Further, the media are seen to play a significant role in offering a socializing influence on the attitudes, beliefs, and behaviors of their audience (Gunter, 1995). The images and texts that are seen within all mass media in general "become a part of the culture of a society and become the basis on which new images and words are created" (Hazell \& Clarke, 2008). Evidently, the mass media are a powerful resource through which viewers develop their identity in the real world (Morawitz \& Mastro, 2008). Further, because the material can be very influential on the ideologies of the audience, where the combined ideology of enchantment and innocence within these films help children to understand who they are and what society is about (LaCroix, 2004), thus, the main aim of this research is to examine the messages delivered about the Arabian discourse and its identity.

Rahayu et al. (2015) in their study compare the folktale "The Story of Aladdin" from the Arabian Nights and the animated film produced by Walt Disney Feature Animation under the title "Aladdin" (1992) showing the shifts of ideology and discourse.

("Aladdin" in the Eyes of Disney 2019...) Dr. Yousreya Ahmed Alhamshary 
The findings show that Disney's Aladdin campaigns ideology that refers to the American values such as freedom and heroism. On the other side, the discourse of Arab barbarism is developed with the practice of stereotyping like labeling the Arabs as barbaric, bad, silly, and wicked as well as dangerous in addition to removing the Islamic messages and values existing in the original tales of the Arabian Nights. Disney's Aladdin ideologically removes the Islamic messages and values and changes them into American values.

In another study by Zitawi (2008), she investigates the adopted strategies by Arab translators in contextualizing Disney comics within the Arab culture, with special reference to Gulf translators and Egyptians. The researcher attempts to analyze the way Disney characters have been portrayed in the target text and investigates the new dimensions added to Disney characters' performance, speech, actions, and so on. She concludes that reordering, addition, repetition, visual manipulation, omission, and exploitation are the strategies used by the Arab translators to contextualize Disney comics within the Arab culture.

In a study by Benhamou (2014), she examines the evolution of the display of race, focusing on the film texts and their historical and cultural context, production history, and critical reception. She argues that the apparent messages of tolerance and promotion of multiculturalism were accompanied and slowly replaced by a color-blind erasure of race.

In another study by van Dam (2014), he deals with the history of Disney's princesses and heroines who have long captured the minds and hearts of young girls with their magical clothes. He addresses the fashion symbols in a chosen set of animated movies and relates this to children's reception, sexuality, and gender issues and narrative identities. In his study, a semiotic analysis of the selected movies and relating them to

("Aladdin" in the Eyes of Disney 2019...) Dr. Yousreya Ahmed Alhamshary 
literature shed light on this subject. He concludes that a young girl as a viewer is fundamentally being taught that the feminine stereotype is the standard expectation of what they are ought to be in their adolescent and adult life.

A recent study by Hedenmalm (2012) with specific focus on gender aims to display what type of values the language in Disney movies reflect. The language of female characters is investigated, and specific features are identified and compared to that of the male. The selected movies for the study include both male and female human characters. Results are not consistent, and the female characters use a language that reveals repression of women to a certain extent; specific male characters do as well. Disney's women resist when exposed to discrimination. Young girls are provided with capable and strong role models. This shows that Disney movies stress the equal value of men and women.

Another study about gender roles in nine of the Disney Princess movies is performed by Collier-Meek et. al (2011) to identify masculine and feminine characteristics and behaviors and examined whether these were normally possessed by male or female characters. The findings revealed that, in most of the movies, the princes display more masculine than feminine characteristics, even though, in more recent ones, they increasingly obtain more female qualities as well.

From the previous studies and others not mentioned here, one can predict the great importance of Disney and the produced films to both the producer and the viewer and even to the linguists. Different areas of research are investigated, and different results are also gained. Still there will be numerous studies and areas for research to investigate about the communication among cultures and the present study is one of them.

("Aladdin" in the Eyes of Disney 2019...) Dr. Yousreya Ahmed Alhamshary 


\section{Data Analysis and Discussion}

Language reflects and is influenced and shaped by culture at the same time. In the opening song, the narrator describes the Agrabah representing the Arabian culture as a land faraway with the specific characteristic of roaming caravan camels. The place with many roaming caravan camels refers to the desert areas in the Middle East countries. The most critical description is that it is "chaotic" but "it's home" with "fabled bazaars" and "with the cardamom-cluttered stalls" and "the silks and the satin shawls." In the film, the Arabian cultural community setting is displayed by the characters in the market scene. As for characters, Aladdin is physically portrayed in a different manner from the other characters in the Arabian society. Aladdin is presented as a young, handsome, athletic, "modern man looks" with light-color skin, and all "good" characteristics with modern fashion clothes. The other characters are portrayed as Arab with dark skin, having beard, and mostly as wicked, bad, or poor persons. Examples of these persons are the fruit vendor in the market who is represented as an ugly big man, a cruel vendor with big knife at hand, and the poor women with her children when Aladdin gives them the date; moreover, the guards are portrayed as a group, all having a big body, dark skin, and wicked or silly facial expression and they always bring swords whenever they chase Aladdin and, in the scene, where women stole Aladdin in the market. Further, the villain, Jaffar, is a dark-skinned man, in tall figure with a long black coat, dark and scary face and mysterious wicked agenda so that he is phrased in the film as "a dark man with a dark purpose." Therefore, the light-skinned people relate to goodness and heroism; furthermore, the dark-skinned people is stereotyped as villain or bad people (Young, 1996). Aladdin's character in Disney is constructed as the hero with light skin and modern looks, with easy-going characteristics and wearing simple modern

("Aladdin" in the Eyes of Disney 2019...) Dr. Yousreya Ahmed Alhamshary 


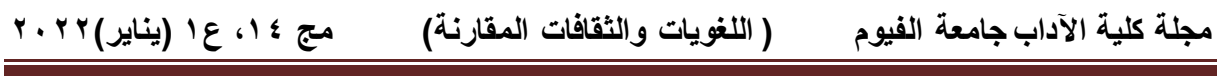

clothes, all of which are identified with goodness. In the following sections, there is much to be represented about the three cultures meant in the below selected images about them.

\subsection{The Eastern poor culture discourse}

The storyline follows the sequence of the original movie; however, the opening scene starts with suspense. Will Smith, who plays the genie's role in the film is a human on a boat with his two kids. He starts telling the story, guiding the viewer to flash back to an Arabian night and the Arabian city of Agrabah where the Arabian cultural discourse is represented. This introductionthough it does not relate much to the Arabian society-is risky. It is the usual way of Disney production, particularly since it does not receive context until the end but serves as an initial hook for those expecting the same old tale. The stars in the movie are from varying countries. However, since Agrabah is fictitious and it never specifies an Arab country, it is only fitting that the actors are from varying Middle Eastern countries. Mena Massoud (Aladdin) is Egyptian, Nasim Pedrad (Jasmine's handmaiden) and Navid Negahban (the Sultan) are Iranian, and Marwan Kenzari (Jafar) is Tunisian. Interestingly though, Naomi Scott (Jasmine) is a British actress whose mother is Ugandan with Indian descent, neither of which are Middle Eastern.

\section{Screenshot 1: film Aladdin: min 0:04:50-0:04:59}

All images' interpretation is based on Kress and Van Leeuwen (1996). Picture one is an offer type of "image act." It represents much information to the viewer about the Arabian society like clothes, buildings, and tools of life. All characters in the scene are giving their back, meaning giving information to the viewers not asking for or "demanding." The choice of distance in this image suggests close relations between represented participants and viewers. Also, the medium long shot in the image shows the full

("Aladdin" in the Eyes of Disney 2019...) Dr. Yousreya Ahmed Alhamshary 


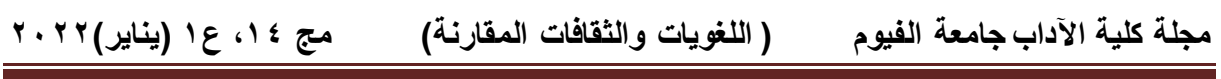

figure of people referring to a complete vision about the Arabian society.

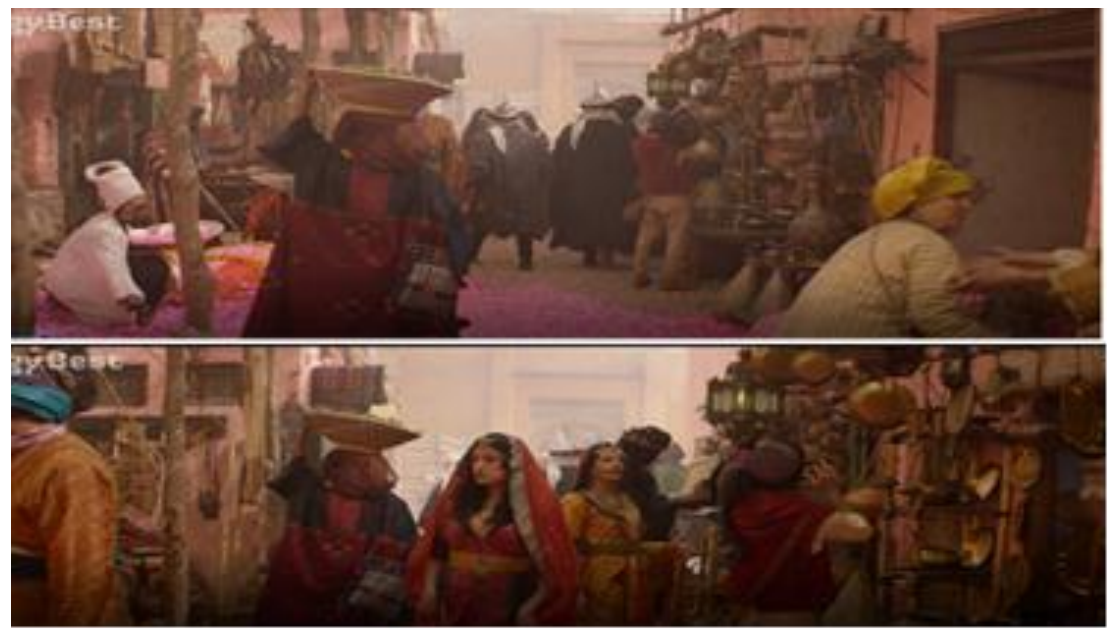

There are many details in the scene for the viewer denoting a complex Arabic society, full of different folds, and when looking at any point one should consider the whole. At the same time, any part of it represents the culture of the whole. Close social distance is represented by the crowd of persons in the scene, the sequence of their position indicating closeness in thought and habits, closeness and informal relations by men and women with the same activities of business as being in a marketplace representing the exact context of modern life in malls and cafés.

\section{Screenshot 2: film Aladdin: min 0:08:16}

In Screen 2, the scene is very expressive and fully indicates Arabian life. Narrow streets with very close walls and at the very bottom a mess of furniture in the street to represent poor social life. A high angle makes the Arabian people look small and insignificant. Most of the scenes about the Arabian society are seen from the above. A low angle makes represented participant's look imposing and awesome: generally, low angles give an impression of superiority, exaltation, and triumph. This is seen in very rare scenes related to the princess Jasmine and Aladdin. For

("Aladdin" in the Eyes of Disney 2019...) Dr. Yousreya Ahmed Alhamshary 


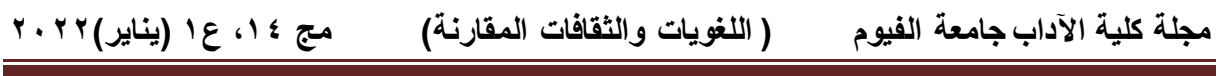

Martin (1968, pp. 37-38), 'high angles tend to diminish the individual, to flatten him morally by reducing him to ground level, to render him as caught in an insurmountable determinism."

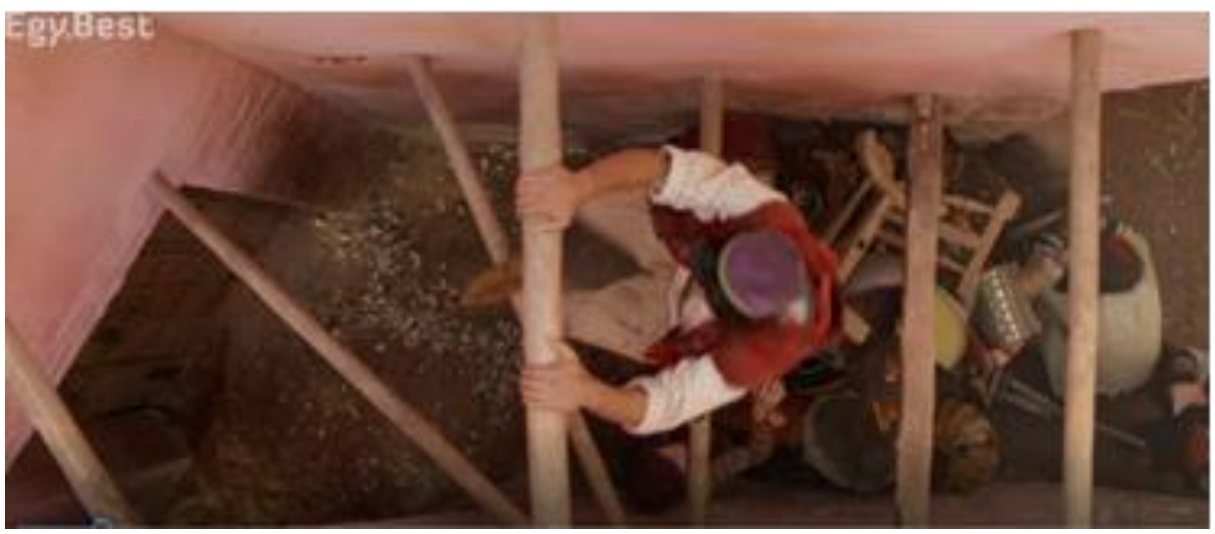

\section{Screenshot 3: film Aladdin: $\min$ 0:06:08}

Kress and Van Leeuwen (1996) point out that if a represented participant is seen from a high angle, then the relation between the interactive participants and the represented participants is depicted as one in which the interactive participant has power over the represented participant or the represented participant is seen from the point of view of power. This is seen in the screen where Jasmine stands in a position upstairs and looks at Aladdin from an upper view which means that she has the power over him. Finally, the picture is at eye level, and then the point of view is one of equality and there is no power difference involved. In the marketplace, all represented participants are seen at the eye level. In the following screen of Jasmine with Aladdin in his house, Jasmine is a princess with power in front of Aladdin; she is seen as looking at him from an up shot. While the top-down angle is the angle of maximum power of both Aladdin and Jasmine, the frontal angle is the full involvement of both. Arabian cultural discourse is mostly viewed from above and the cameras' shot comes from above to transfer to any side (the normal view

("Aladdin" in the Eyes of Disney 2019...) Dr. Yousreya Ahmed Alhamshary 


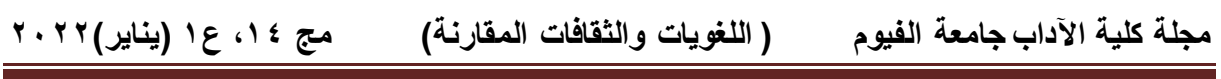

position), yet a maximum representation of pictorial detail is present in mostly all the scenes. Detailed engravings are found in every part.

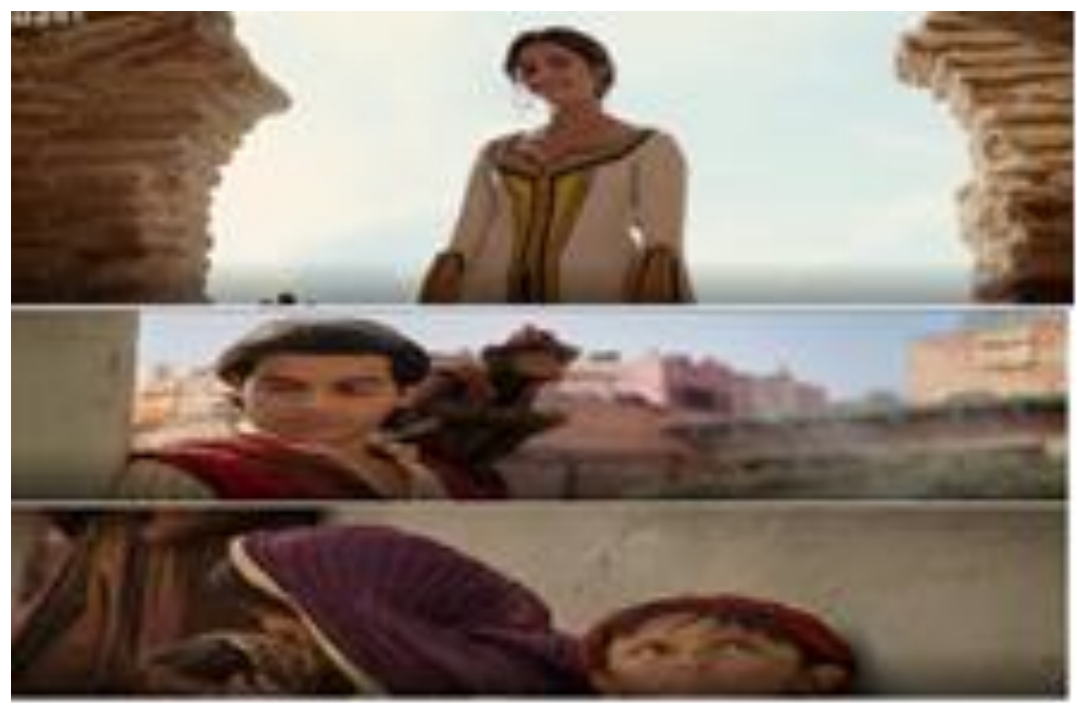

This may be because the producer wants to give a total complete shot to the whole society and environment. One will not see the whole of the building, as is (again) often the case in film shots in which the building is related to some action and movement. Personal language is casual, with a good deal of colloquialism and slang with some code-switching words like "يلا يلا". The angle is high and frontal and so conveys power over and involvement with the represented participants. Image two represents the superiority of Aladdin as a person having food in front of the poor family. The sequence of shots and the text sequence narrativize the relation between the represented and the interactive participants. These pictures in general are full of details, full-color saturation, and sharpness; therefore, they are closer to be natural and hence closer to modality.

("Aladdin" in the Eyes of Disney 2019...) Dr. Yousreya Ahmed Alhamshary 


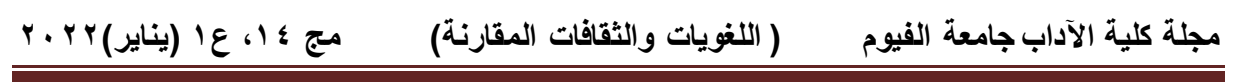

\section{Screenshot 4: film Aladdin: $\min$ 0:06:27}

The Screenshot four though has many details; it assures the unimportance of the Arabic society with its small and many details. It has unusual items like having shops at the upper floor of houses. The umbrellas in the upper image represent modern-life features and covered details. The clothes of people represent the middle age style even with the soldiers having tiny hats. The image represents their silly weak position in society as they are standing on air and falling however upon people's head.

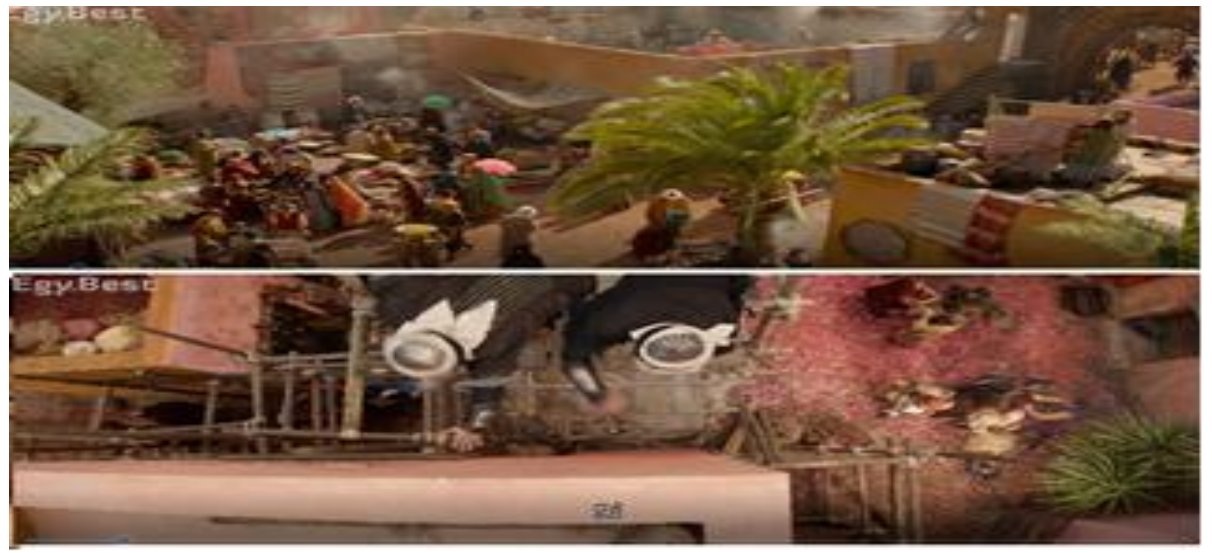

Screenshot 5: film Aladdin: $\min 0: 31: 33$

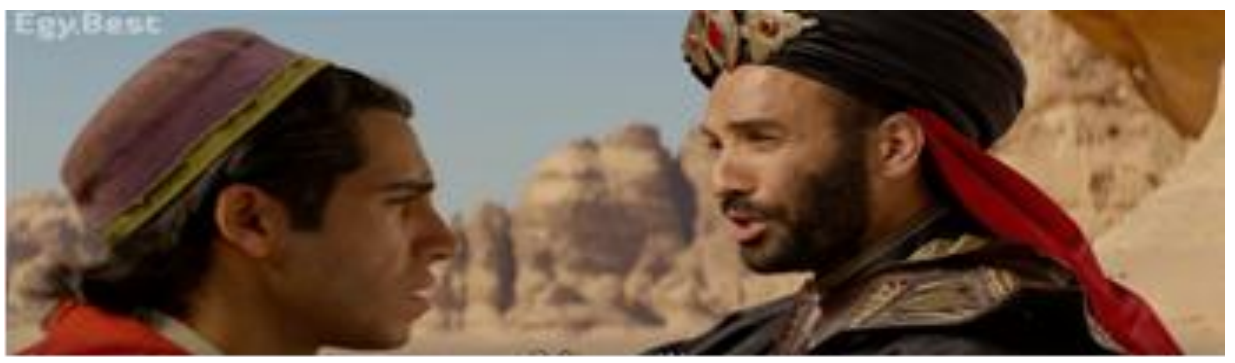

Aladdin is on the right as a "given" character which means known to everyone whereas Jafar in the left as a "new" or minor character in the film. Both are in this position equal in eye level but at the same time they are looking in different directions means that they are different in their thoughts or style of life or social status. The two hats are different in color and frame. Where Jafar's is dark black big and decorated to indicate luxurious and

("Aladdin" in the Eyes of Disney 2019...) Dr. Yousreya Ahmed Alhamshary 
soft life further evil and bad character, Aladdin's is light purple small, and its border is old indicating hard life and misery as if they are facing their future. The background is indistinct indicating hardness of the place. The light is facing Jafar with stable relaxed glance at his face to the future, contrasting Aladdin's future with his anxious glance of his face to his future. Jafar is looking at the unknown - here the lantern and the power of genie - whereas Aladdin is looking at the known however Jafa is not worried, but Aladdin is. If so, these affective, personal clear meanings are surely as significant as social and cultural meanings representing their identity and cultural discourse.

\section{Screenshot 6: film Aladdin: min 0:31:15}

This pictorial image is expressive. The saturation of yellow color is representing the desert environment, and nearly $30 \%$ of it is very dark and distributed in the right and left to create stability of view. The camels are four and have equal distance among them which means organization and continuous movement. The background slant sun light makes shadow in the desert to represent the inflate surrounds and mountains. Their direction is from the unknown to the known. This view transfers the viewer to the western environment by removing many details about the Arabian society. The percentage of people to the free space in this view may represent the percentage of area of housing to the area of desert life in the whole geographical area of the Arabian countries.

("Aladdin" in the Eyes of Disney 2019...) Dr. Yousreya Ahmed Alhamshary 


\begin{tabular}{|c|c|c|}
\hline 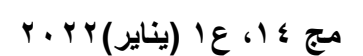 & ( اللغويات والثقافات المقارنة) & مجلة كلية الآداب جامعة الفيوم \\
\hline
\end{tabular}

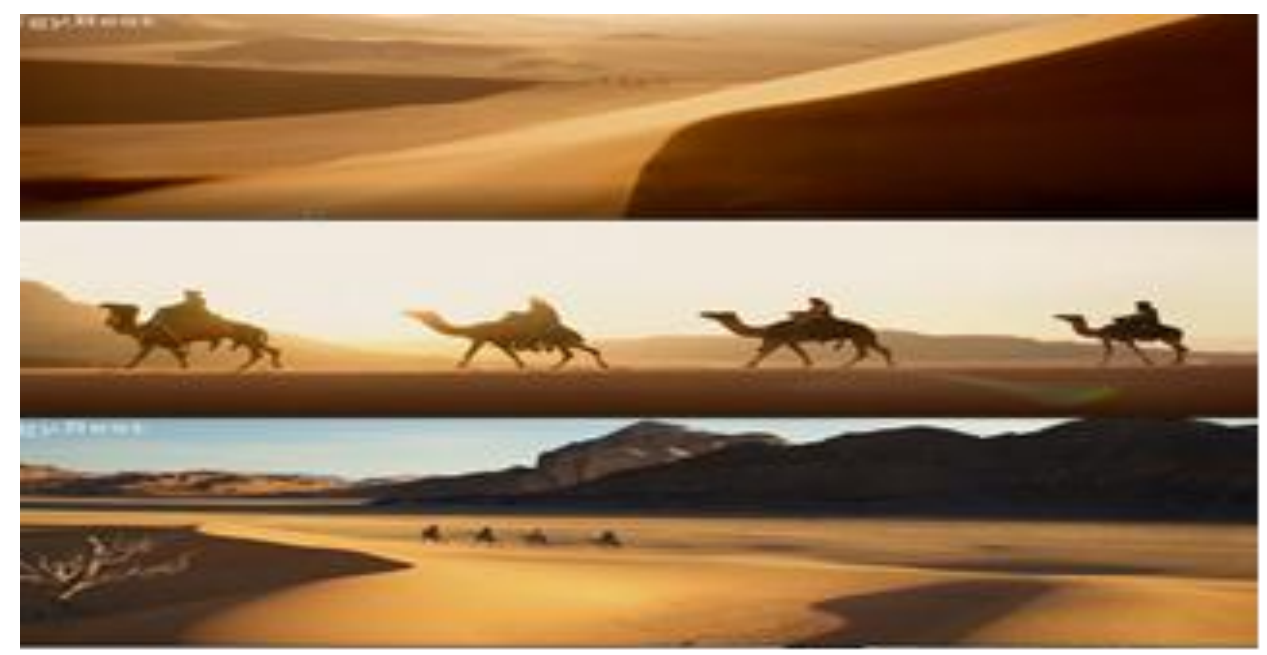

In this image and most of the other scenes, the characters are presented as centric which means that they are presented as the nucleus of the information to which all the other elements are in some sense subservient. The margins of the images are these ancillary, dependent elements, and, in many cases, they are identical or at least very similar to each other so that there is no sense of a division between Given and New and/or Ideal and Real elements among them (Kress \& Van Leeuwen, 1996). This picture plays the role of transitional area with saturated colors making harmony with the Arabian environment. The upper picture represents the full dryness of the desert and shadows with dark yellow color. The direction to the left or dark part represents their direction to the unclear future action of Aladdin and Jafar. It gives the viewer a linear reading of their direction. These pictures contain fewer details in the surrounding environment.

\subsection{The eastern rich cul ture discourse}

This part is about the palace with luxury features and soft life. The first scene where the prince comes to get engaged to the princess comes with the middle shot where there is equality. The prince has a hat, clothes, and white skin representing his identity being different from the eastern society. The repetition of the

("Aladdin" in the Eyes of Disney 2019...) Dr. Yousreya Ahmed Alhamshary 


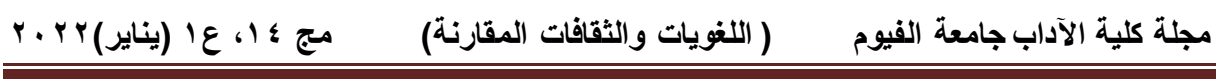

golden color in all the elements of the two pages provides a strong sense of unity and cohesion which further recalls harmony with the Arabian rich environment.

\section{Screen 7: film Aladdin: min 0:19:13}

The princess is in the center facing the viewer at eye level which indicates her principles of equality. The background and walls represent the eastern decoration parallel to luxury life. The two closest characters to the princess are in the same position at the back.

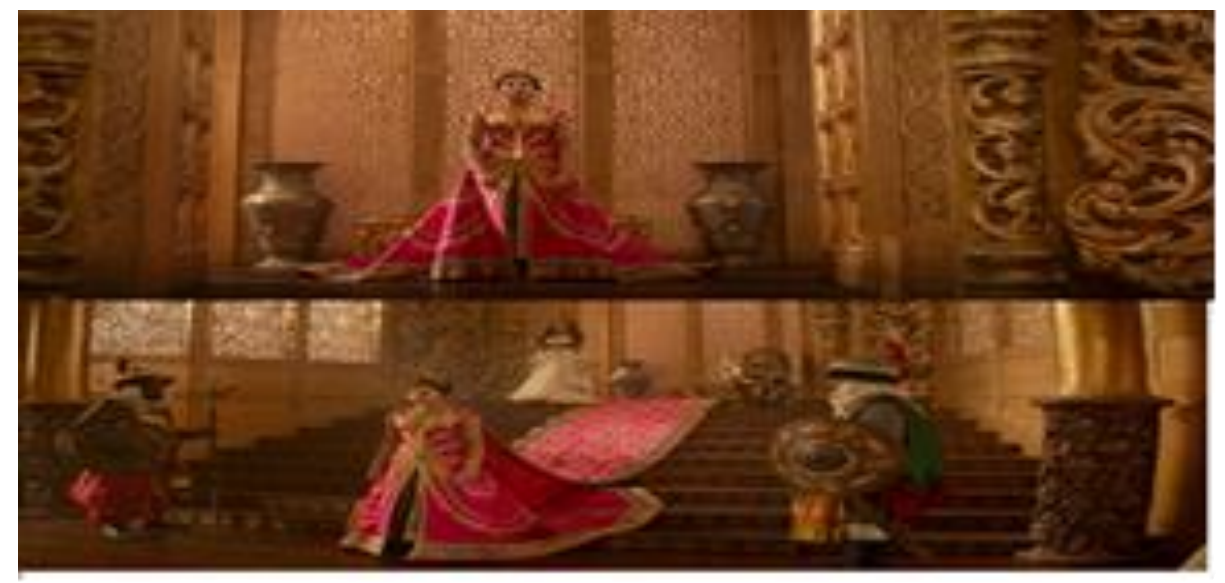

Her position at the two pictures is centralized which may indicate stability and fairness or clear steps towards her concepts. Her clothes are closer to Indian women in design and color. Her position in the center is visually joined to other people in the image, through the absence of framing devices, through vectors, and through continuities of her steps or the similarities of color around her. Color plays a very powerful role and is considered a key element in the film. Color is used and seen according to each culture's concept. People use it to present themselves and the values they stand for in the context of specific social situations. Dark colors are used with the poor to indicate misery and hard life whereas cheerful and clear soft colors are used with rich people to

("Aladdin" in the Eyes of Disney 2019...) Dr. Yousreya Ahmed Alhamshary 


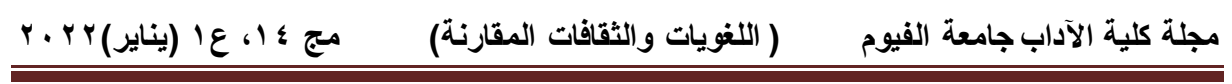

indicate easiness and happy life. Colores are used to reflect on people's life.

Screenshot 8: film Aladdin: $\min$ 00:59:20

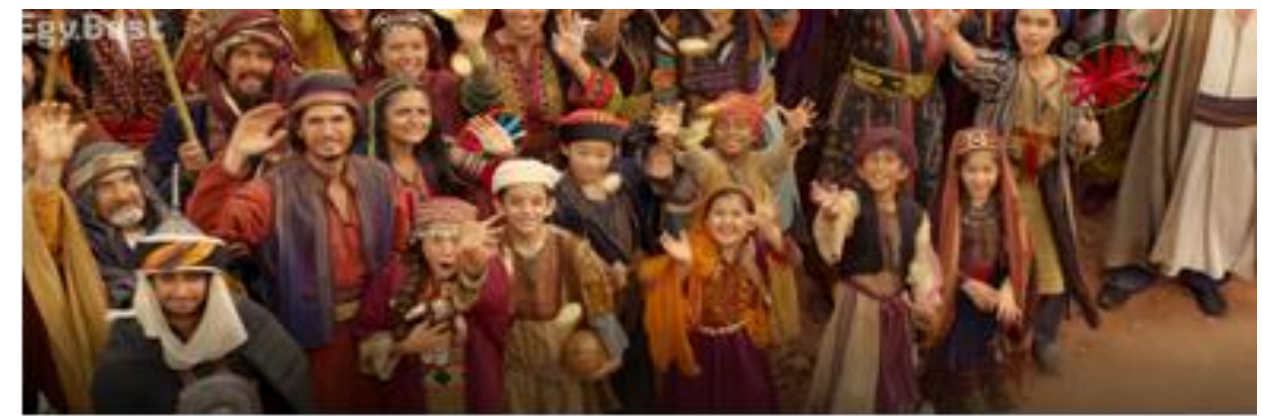

This image represents numerous faces including Southeast Asia with their clothes and style of living; however, all of them are produced as poor societies that look at the camera shot from a top view. Most of the attendees in the scene are young children who indicate future and present status of the eastern societies.

Screenshot 9: film Aladdin: $\min$ 01:08:29

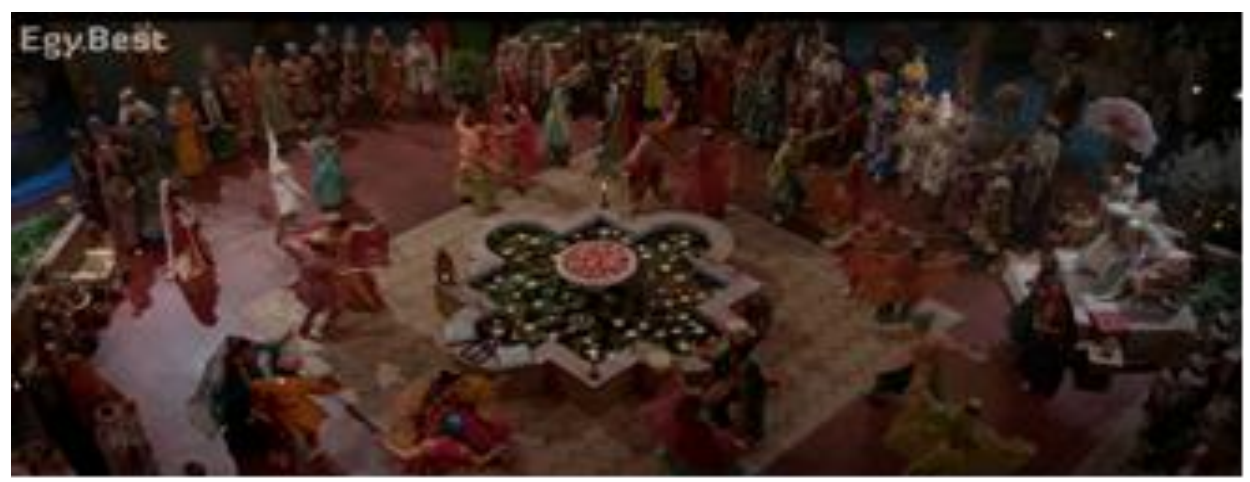

Throughout the Arabian discourse, there are many instruments and materials related to the Arabic discourse like the carpets in the marketplace, the oud instrument, a lantern which is different from that found with the genie scene, clothes style, and even the decoration. The whole scene in the image represents the Indian discourse in color, dance type and music or decoration. The camera comes from the upper shot to represent many of the details in the scene.

("Aladdin" in the Eyes of Disney 2019...) Dr. Yousreya Ahmed Alhamshary 
In another part of the film, in the middle of the eastern poor and rich discourse comes a part referring to the western cultural effects on the eastern culture. This position as a place in the film means that the western culture is embedded in the eastern one and deeply imposed in the Arabian discourse. Many eastern features are represented in numerous screens associated with the genie (Smith) that represent the eastern identity in the film as will come later in the analysis. As a sequence of the film, the introduction to the genie appearance is in a vague environment, as who can resist seeing Smith painted in blue with a hair knot on his bald head? With that aside, Smith adds his own touch of humorous responses that make genie even funnier. Smith is a human version of the genie and a representative of the western culture. The characteristics of the genie throughout the film give so much about the eastern discourse features. The power of the genie this time is not a type of supernatural powers but a type of modern facilities in the eastern daily life or abilities of the eastern societies. Some examples of that will be in the few following lines.

\section{Screenshot 10: film Aladdin: $\min$ 0:34:09-0:50:30}

In this image, the path that Aladdin is walking through is not clear or paved but rather dangerous and full of stone bumps. It is represented as a vague place full of darkness that is a symbol of the world of unknown. The outside world is seen as a very small point of light behind Aladdin.

("Aladdin" in the Eyes of Disney 2019...) Dr. Yousreya Ahmed Alhamshary 


\begin{tabular}{|c|c|c|}
\hline 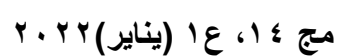 & ( اللغويات والثقافات المقارنة) & مجلة كلية الآداب جامعة الفيوم \\
\hline
\end{tabular}

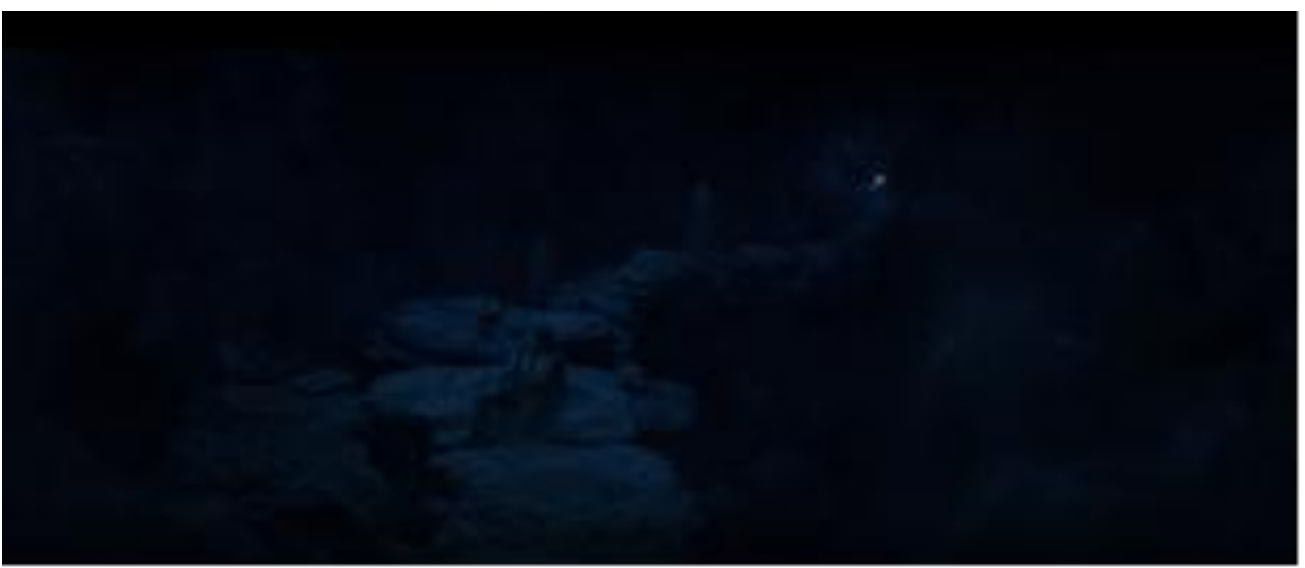

His face is directed to the left which is a representative of the unknown. He is centered in the image and the black or light black color is the common color in nearly $99 \%$ of the picture. Once anyone gets in the cave or the eastern discourse, they start to see and be impressed by the temptations inside represented by the jewels, gold, and gemstones which are translated later by the modern-life features through the genie's interactivities with Aladdin. Friendship of the eastern people is represented also by the first shake of hand with the carpet. All these temptations are subjected to being inside the cave or the western society.

("Aladdin" in the Eyes of Disney 2019...) Dr. Yousreya Ahmed Alhamshary 


\begin{tabular}{|c|c|c|}
\hline 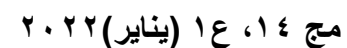 & ( اللغويات والثقافات المقارنة) & مجلة كلية الآداب جامعة الفيوم \\
\hline
\end{tabular}

Screenshot 11: film Aladdin: $\min$ 0:34:09-0:50:30

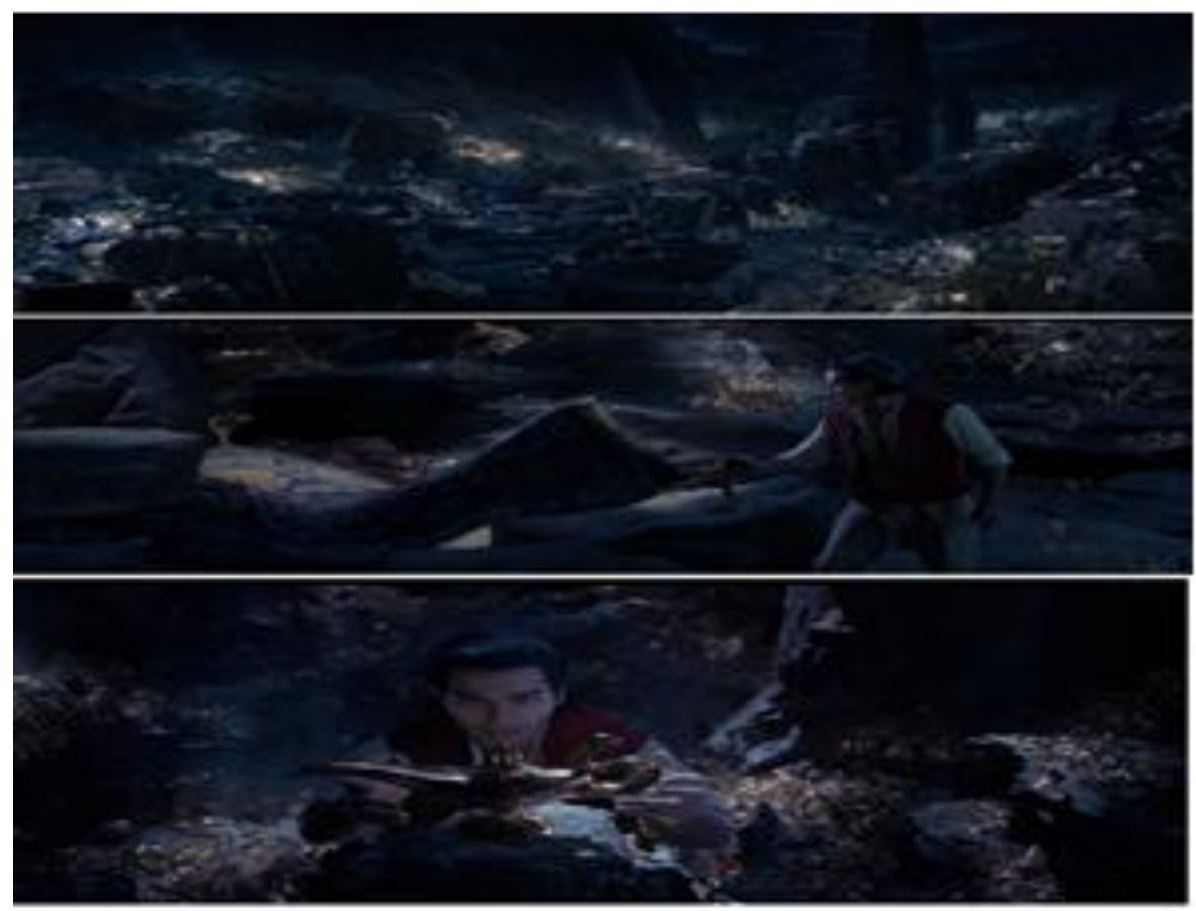

The space and brightness in the picture are impressive, indicating loneliness of people like Aladdin in the western society. The focus on Aladdin's face here is also intendedly represented to give relaxation and offer the viewer the same feeling that he reached his target. The ideology of the western societies is represented in the movement and options given during the genie's first meeting with Aladdin.

(“Aladdin" in the Eyes of Disney 2019...) Dr. Yousreya Ahmed Alhamshary 


\begin{tabular}{|c|c|c|}
\hline 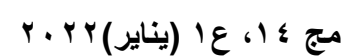 & ( اللغويات والثقافات المقارنة) & مجلة كلية الآداب جامعة الفيوم \\
\hline
\end{tabular}

Screen 12: film Aladdin: $\min$ 0:57:00

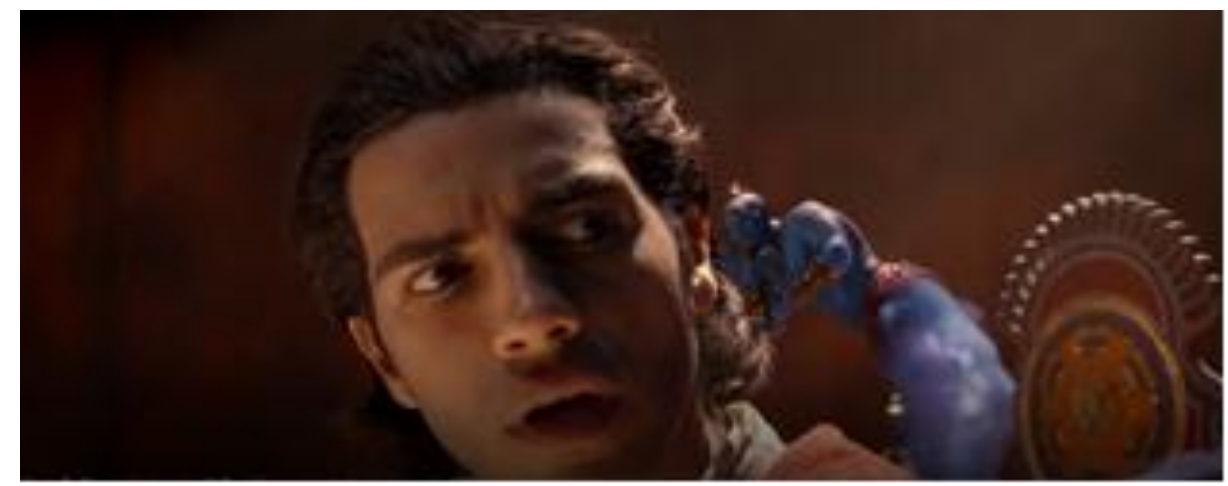

The opposite position of Aladdin and the genie is impressive here: the genie is small, and Aladdin is big. The genie takes the position of whispering to him and Aladdin is impressed.

Screenshot 13: film Aladdin: $\min$ 0:34:09-0:50:30

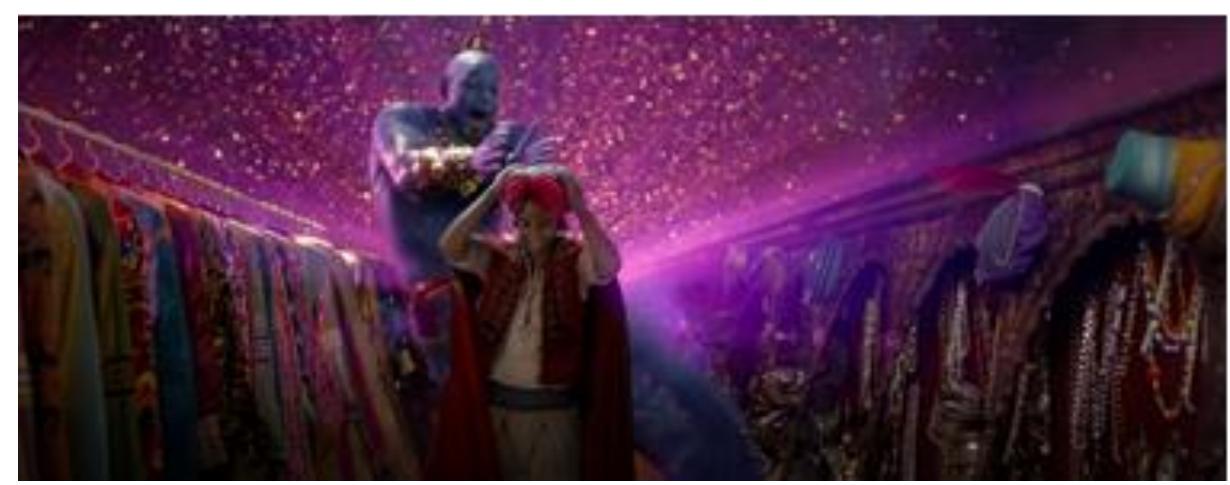

Here start the features of the genie representing the Eastern culture that it has numerous frames and can be dressed in different clothes. Each country in the west has its own frame or style of cloths Aladdin here does not have the power to choose as the genie is doing all the changes to him and at the same time these changes pleased Aladdin. The light comes from the very back of the genie. The many different types of clothes did not change the nature of Aladdin and this comes true at the end of the film when he said to Aladdin, "I did not change you from inside" as Aladdin cannot talk to Jasmine.

("Aladdin" in the Eyes of Disney 2019...) Dr. Yousreya Ahmed Alhamshary 


\begin{tabular}{|c|c|c|}
\hline 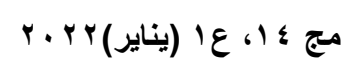 & ( اللغويات والثقافات المقارنة) & مجلة كلية الآداب جامعة الفيوم \\
\hline
\end{tabular}

\section{Screenshot 14: film Aladdin: mins 0:34:09-0:50:30}

This picture politically represents the Arabic figure Aladdin as an agitated doll with strings and a western figure that can obtain an intended result. This image represents the struggling of the Arabic figure for the movement trying to move by himself and get free movement. However, the bottom figure shows his head downward and his still stand, indicating the passivity and capitulation for the western control over the Arabic movement. The vague and dark colors also control the scene.

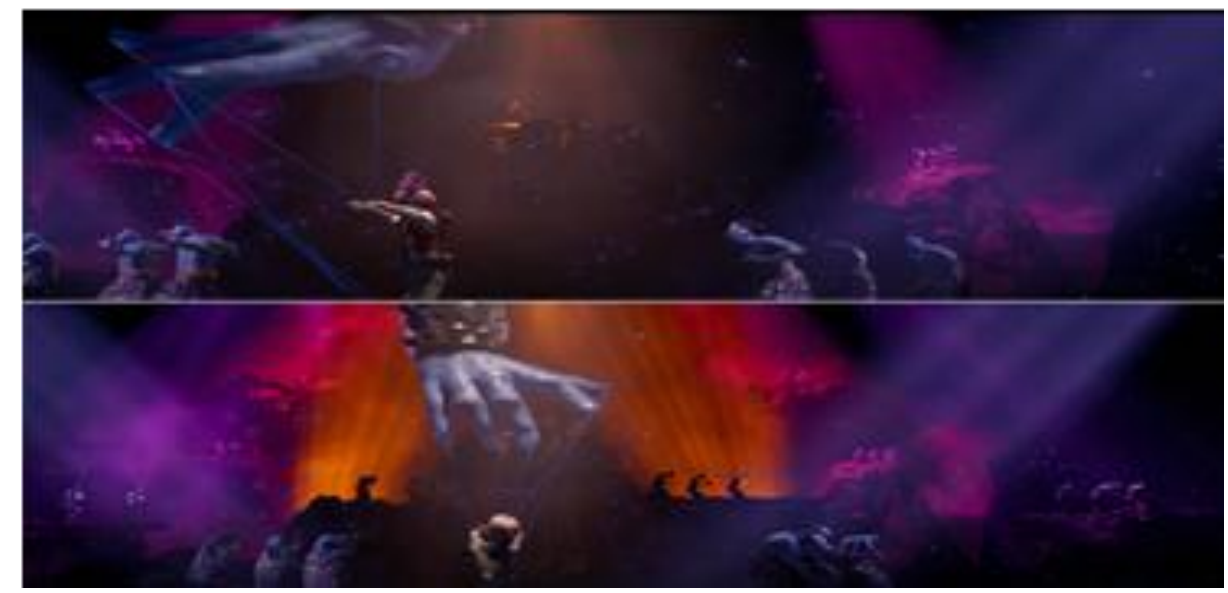

Both images represent the upper hand of the western culture upon the Arabic one. The camera shot comes from the front indicating equality to the viewer and the genie's hand only is present in the scene to indicate the absence of western entity existence.

Screenshot 15: film Aladdin: $\min$ 0:34:09-0:50:30

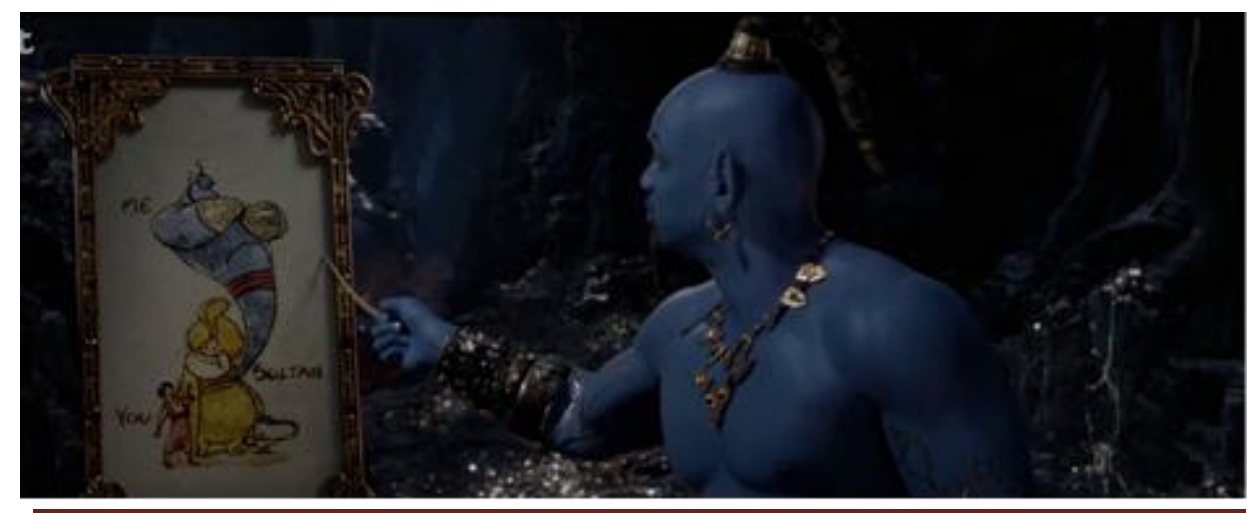

("Aladdin" in the Eyes of Disney 2019...) Dr. Yousreya Ahmed Alhamshary 
This image represents the hierarch of power of the three entities in the scene. The genie is telling the viewers and the Arabic community that he has the total power control and the sultan indicating richness and wealth of gulf countries has the next position and Aladdin as one of the poor has the last position as he has no power or wealth. The genie's position being on the right side indicates that the entire world is viewing and evaluating the power of each one representing his culture in this way. He is convincing Aladdin by the hierarchy of power as reflected in the picture. Aladdin presented himself as being unaware of this fact when he indicated that he does not know the real power of the genie. The genie though has a glass and an apple, and he can obtain all objects as a symbol of having all facilities; however, he is imprisoned to the Handcuffs and cannot be free.

The representation of the three cultures in this sequence is impressive as the story starts with the Arabian nights as a source of the story. Then, it gradually transmits from the Arabian to the western culture by the features granted to the genie. Then, it is moving back to the eastern culture by the actions in the palace. This gradual movement without separation shows the interaction between cultures and the interactivity of each one. Kress and Van Leeuwen (1996, p. 64) pointed out that "Visual structures do not simply reproduce the structures of 'reality'. On the contrary, they produce images of reality which are bound up with the interests of the social institutions within which the images are produced, circulated and read," which means that Disney is representing the social context in the way they like to or representing their ideology in a film form as stated also on page 64 that "They are ideological. Visual structures are never merely formal: they have a deeply important semantic dimension."

("Aladdin" in the Eyes of Disney 2019...) Dr. Yousreya Ahmed Alhamshary 


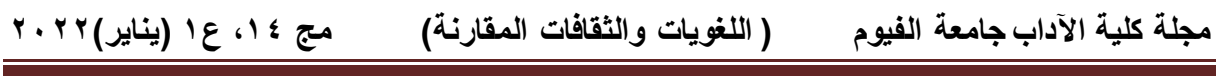

Screenshot 16: film Aladdin: $\min$ 0:34:09-0:50:30

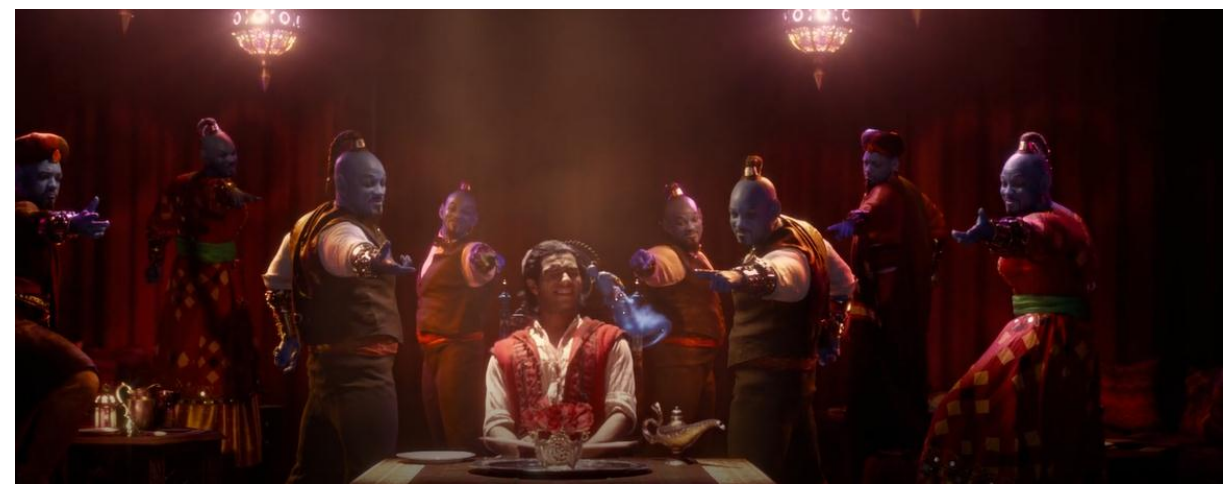

Apparently, participants in the image can present their separate identity to different degrees but still the Arabic in the middle. When they are conjoined as in the previous image, the process, the act of connecting them together, is still explicit and realized by a line. When they are compounded again, their identities remain distinct, but there is no longer an explicitly expressed process to connect them. When they are fused, even their separate identities have disappeared.

When the film first premiered in 1992, there was one line in this opening song that said, "where they cut off your ear if they don't like your face. It's barbaric, but hey it's home!" This created uproar among Arab American and Muslim Americans, who believed this lyric made their culture seem violent. It was not until the media began to support the uproar that Disney changed the lyrics to, "where the land is immense, and the heat is intense. It's barbaric, but hey it's home!" (Pinsky, 2004, p. 153). In the last version 2019, this line is changed to "It's chaotic, but, hey, it's home" where the word barbaric is changed to "chaotic." Although the word meaning became less hostile, it still includes the offensive meaning for the Arabian identity. After the release of the 1992's version of Aladdin, the terrorist attacks of 9/11 occurred later. As a result of the portrayals of Arabs within

("Aladdin" in the Eyes of Disney 2019...) Dr. Yousreya Ahmed Alhamshary 
Aladdin, Mark Pinsky states in his book The Gospel According to Disney, "It will be many years before American children will be able to watch Aladdin without connecting the characters with our image of Arab terrorists" (Pinsky, 2004, p. 153). Now the children and even adults can see the character of Aladdin without the view of terrorism or hostility but still with a negative attitude or chaotic personality. Attached with this view is the positive side of the Arabian character like being kind and compassionate when he helped the lady who by herself helped the poor and when giving his only food (date) to the poor child. At the end of the film, the Arabian value of granting freedom to the genie is so impressive, for Aladdin preferred to lose money and authority to grant freedom to the genie as an establishment of the base of altruism in Islam. This simultaneously changes the attitude positively toward the Arabian character.

As Kress and Van Leeuwen (2006) point out, the ability of modern color photography to render detail, brightness, color, and so on constitutes for our culture today a kind of standard for visual modality and further there is a belief in photography as being capable of capturing reality as it is. Scott portrays Jasmine beautifully. Similarly, Massoud is perfect as Aladdin, so much so that his voice is nearly identical to the original Aladdin's because of his Arabian dialect. Even Jasmine's tiger, Rajah, looks real. One of the points of view that the film can be critically seen by the Arabs is the inaccuracy in representing cultures. While "Aladdin" is not perfect, it is a step up in cultural representation through traditional Arab decor and architecture. This includes traditional tea glasses, open rooms such as Jasmine's bedroom, water-an important Arab symbol-inside during the harvest party scene and the busy, colorful market filled with spices and fresh food, and other Arabian features like those presented in the above images.

("Aladdin" in the Eyes of Disney 2019...) Dr. Yousreya Ahmed Alhamshary 
Aladdin is created to be lifelike musical film in the last version 2019. Three different types of songs are included in the film: ones that only sound Middle Eastern, others that only sound like a western musical, and those that are a blend of the two sounds. It is very difficult and amazing to have Middle Eastern symphony with an Arabic rhythm. To evoke a Middle Eastern sound in Aladdin, some special musical techniques are used like a focus on using voice which is common in Middle Eastern music. Another technique is an instrumentation of mostly percussion, string, and wind instruments. Further is the high use of decoration and ornamentation to imitate Middle Eastern micro-tonality. Although the story of Aladdin is based on the story from the famous novel One Thousand Arabian Nights, the Disney film features the talent of comedian Will Smith, adding a comedic element to the whole film, including songs, such as Friend Like Me. As a result, the film is more of a comedic American animated musical that takes place in the Middle East rather than a Middle Eastern film that has been presented as a lifelike musical one. Jasmine's wardrobe and the Arab Majlis sofa in her bedroom display traditional silk. But the culture is best represented in the Arab architecture. Jasmine's room and others have horseshoe arcs with alternating white stone and red bricks as seen in the Mosque of Cordoba, Spain. There is also an indication of repetitive architectural designs, traditionally made from plaster or wood with geometric symbols, vegetation, and calligraphy which all represent religious designs.

If there is an aspect that could have been changed for more cultural context, it would be the lack of accents. While Disney movies are notorious for using American accents in movies about other cultures, it stands out most in this movie. Adding more Arab accents than the simple rare words used in some context could have added that extra cultural touch. The original "Aladdin" is

("Aladdin" in the Eyes of Disney 2019...) Dr. Yousreya Ahmed Alhamshary 
known for its iconic soundtrack. While the new version keeps these songs, it alters a few lines such as adding a rap part to "Friend Like Me" for a comic twist and adds a few songs such as "Speechless." This keeps the music interesting while remaining classic. Disney homes in on female empowerment and steers away from the criticism of the damsel in distress stereotype. Jasmine desires to be the next Sultan and insists she has the strength, knowledge, and care for the kingdom needed for the role. In response, she is told to be seen and not heard to which she responds that she won't be silent. This is captured in her song "Speechless." This is a turning point for Disney. It is great for a young girl to dream of being a princess, but it is even better if they can be inspired to be strong women with limitless potential. One observes from the "low-angle that a "long shot" could also be observed. There could be buildings, animals, and people shopping and tools or equipment. Viewers are then made to relate to the represented participants in the film in a certain way that attracts them and lets them feel comfort.

Thus, one can conclude that the last version, though the same story, has much to say about the Eastern culture focusing on the Arabian part. There are many negative characters in the previous and current version about Arabs like being silly, poor, aggressive, and deceptive; however, many positive Arabic values are present also like generosity, prowess, altruism, and practice of disinterested and selfless concern for the well-being of others as happened with the poor child, Jasmine, and the genie himself at the end of the film. In the international relation context, the American disseminated image is a hero for many problems of the nation as presented previously by the Disney Corporation company around the world through the cultural production of such animated films. The changing discourse of Arabian Aladdin to be Americanized in the Disney shows that Disney has the agenda to focus on the

("Aladdin" in the Eyes of Disney 2019...) Dr. Yousreya Ahmed Alhamshary 
aspects of "the other" after the 11th of September 1992. In the previous versions or animated films representing Arabic people "the other," they are constructed as silly, wicked, barbaric, scarry, and dangerous and consequently are treated as enemies and bad guys who should be defeated, crushed, and punished, but they are now friends and get help from genie. The real goal of Disney this time is to change American image in the eyes of "the other." Disney is successfully omitting the negative Islamic images and values that exist in the previous tales of Aladdin in Arabian Nights and gradually removes the negative impression about Islamic barbaric image and changes them into "real Arabic". Even the power of the genie becomes restricted to the Arabic hero "the other for the American people" who finally sacrifices his wishes in return of granting freedom to the genie.

Giroux (1996) argues that the characterization of the Other in Walt Disney is not only ideological but also economic to encourage international consuming habits; Walt Disney as an American company aims to represent a non-Eurocentric view of foreign and regional cultures by appealing to the most of its nonAmerican market. However, spreading "U.S. values and ways of life across developing countries," (Belkhyr, 2013, p. 45) in a form of cultural imperialism, is countered by Disney's commercial goal of the "openness and mingling of a multiplicity of cultures" as illustrated by Thussu (2006, p. 146). As previously explained, Disney is repositioning its image within global and especially the Arabian markets by representing the changing American culture view of the Arabian developing countries, and, at the same time, the distribution of this changing American culture to the national and regional cultures. On one hand, it could be argued that it is ideologically "dominating, restructuring and having authority over the Orient" (Said, 1978, p.11). The embedded messages in Disney's works before and in the present film are positively

("Aladdin" in the Eyes of Disney 2019...) Dr. Yousreya Ahmed Alhamshary 
promoting social reform which is contrasting with the clear American hegemonic ideologies indicated by political practices in the world. These changing attitudes towards the treatment of class minorities, race, and gender are evident in Disney's works.

\section{Findings and results}

Based on the previous analysis and discussion of the selected pictures, one can conclude that many explicit manifestations of three identified cultures and visible features in addition to both Arabian and American cultural aspects and ideologies can be summarized as in Table 1.

\section{Table 1. Three identified cultures and their visible features}

\begin{tabular}{|c|c|c|c|}
\hline $\begin{array}{l}\text { Culture } \\
\text { Features }\end{array}$ & Arabian & American & Indian \\
\hline Language & $\begin{array}{l}\text { Some expressions like } \\
\text { (يلا يلا) and all names }\end{array}$ & $\begin{array}{l}\text { The whole film is } \\
\text { English }\end{array}$ & $\begin{array}{l}\text { The tiger's name } \\
\text { is Raja }\end{array}$ \\
\hline $\begin{array}{l}\text { Arts } \\
\text { (music, } \\
\text { dances) }\end{array}$ & $\begin{array}{l}\text { Speechless song, } \\
\text { cinemas screens, } \\
\text { arabesque furniture, } \\
\text { curtains, decoration in } \\
\text { the palace, music } \\
\text { instruments }\end{array}$ & $\begin{array}{l}\text { Jazz, rock pop } \\
\text { music and disco } \\
\text { drums, cinemas, } \\
\text { armchairs, music } \\
\text { instruments }\end{array}$ & $\begin{array}{l}\text { Dances with } \\
\text { Indian-like style, } \\
\text { Aladdin asking to } \\
\text { marry Jasmine } \\
\text { and the party at } \\
\text { the end, cinemas, } \\
\text { music instruments }\end{array}$ \\
\hline $\begin{array}{l}\text { Rituals, } \\
\text { customs, } \\
\text { and } \\
\text { traditions }\end{array}$ & $\begin{array}{l}\text { Tea and dates for } \\
\text { welcoming people, } \\
\text { open markets for poor } \\
\text { people, gifts when } \\
\text { going to visit } \\
\text { someone, houses of } \\
\text { mud-bricks }\end{array}$ & $\begin{array}{l}\text { The use of } \\
\text { fireworks, } \\
\text { ceremonies of } \\
\text { getting married }\end{array}$ & - \\
\hline Food & $\begin{array}{l}\text { Dates, apples and } \\
\text { grapes, eastern sweets, } \\
\text { and baklawa }\end{array}$ & Champagne & Spicy foods \\
\hline Clothes & $\begin{array}{l}\text { All the poor and some } \\
\text { of the princess and } \\
\text { Pharaohs stick }\end{array}$ & $\begin{array}{l}\text { Aladdin trousers, } \\
\text { the genie's hair }\end{array}$ & The Indian sari \\
\hline
\end{tabular}

("Aladdin" in the Eyes of Disney 2019...) Dr. Yousreya Ahmed Alhamshary 
So, some displayed ideas as seen by Disney can be concluded in the film as follows:

- Daughters are taught to run the house when mothers are not there. In the Arabian countries, children imitate their parents as Jasmine imitates her father being a courageous Arabian girl and a leader for the country when her father is unable to do so. She visited the poor and follow them up to know more about their life and that is one of her mother's habits.

- Family life is an integral aspect of the Arab culture and loyalty to family life is strong. People know and speak proudly of their genealogy as Jasmine did. The first scene of the film represents that concept where the father teaches stories and wisdom to children. Another aspect of family life is never to look at others good status and be satisfied with one's life as the father informs the children about their small ship.

- Arabic generosity and hospitality are another two values seen along the film. In the market, Aladdin granted the boy his only food (few dates). Jasmine gave the poor children bread in the market. Another value is taking a gift when visiting someone like when the prince comes to ask for marrying Jasmine.

- The life features are clear in the introductory: a song, a faraway land with sands, with caravan camels going here and there, culture and tools, tables of bazars and types of food and spice, and many other features about life and nature.

- Arabic names during the whole film like Khalil, Gamal, Jafar, Dalia, and of course both main characters Aladdin and Jasmine.

- Clothes style for men as Jallabeya with a big hat and women dressed in tall dresses and hijab in the countryside. However, poverty and richness are very clear as indicated in every part

("Aladdin" in the Eyes of Disney 2019...) Dr. Yousreya Ahmed Alhamshary 
of the film which elaborates the gap in people's life and how social classes are very far from each other. In the big image of Arab countries, we have the same view of classes where some are very rich, and the others are very poor.

- Poor people can be good ones as Aladdin is pushed to steal for food and, actually, he is good as he said" if only they look closer, would they see a poor boy? No sir they will find out see so much more on me" and told the monkey "Abo, sometimes we steal" as he did in the market for food "and sometimes we do not, and this was one we don 't" as there is no need. The goodness of Aladdin is proved when he safely entered the cave where only good people can enter and when he was in, he treated the carpet as an arrested human being and set it free as he also did with the genie at the end of the film.

- Arabs in the film think that learning is not enough, and experience is required. Women are not allowed to rule the kingdoms and only men do. Jasmine was reading many books to rule the country but from the father's point of view this is not enough. She is told that dressing well is more suitable for her than telling her opinion; "it is better to be seen not heard" as Jafar said.

- Power of the Eastern identity is formed in the facilities and ability to do anything, having military equipment and modern inventions besides all entertainment tools, and items that make life easier and this is clear from the analysis of the selected images. Still magic play a role in Arab's life.

- A final word about ideology is that both the rich and the poor are very close to each other now, and, in the big image, east is interacting and harmonically communicating with the west. The discourse of western values is constructed through the

("Aladdin" in the Eyes of Disney 2019...) Dr. Yousreya Ahmed Alhamshary 
concept of the genie's characterization of pursuing the freedom to others and giving service to friends.

\section{Conclusion}

The social media network accelerates the communication process and helps in reflecting reality for users. As mentioned in the previous lines, media and films will continue to be the first important and effective way to talk to and affect cultures of people. Disney's Aladdin shows Arabic and Eastern values of freedom and heroism. Thus, the numerous features and characteristics discovered through the analysis indicate that there is a big change in both Eastern and Western countries' nature and style of life. However, simplicity and peace are the clearest features of both societies. Behavior is always greater than knowledge because in life there are many situations where knowledge fails but behavior can still handle representing the issues. Much is written and said about the Arabian people but only behaviors of individuals tell the truth about them. The change in lifestyle is a message to all the world not only the Americans that the Arabian character now is not the same before. Some awareness and modernity in life come true now. The Arab area now is connecting all cultures as a mediated area for trading and work. The negative vision still there; however, it is not adequately clear enough and is mixed with a soft glide to the understanding point. Society cannot be separated from politics, as the latter cast a shadow over society and affect negatively and positively its mood, affiliations, and orientations. What happened in the United States of America on September 11th led the whole world to rethink of the patterns of interaction between societies and cultures. Consequently, the relationship between the West and the East has changed from attack and defense, futile research, and analysis without vision and coming up with unrealistic recommendations about the Arab world to that type of dialogue

("Aladdin" in the Eyes of Disney 2019...) Dr. Yousreya Ahmed Alhamshary 


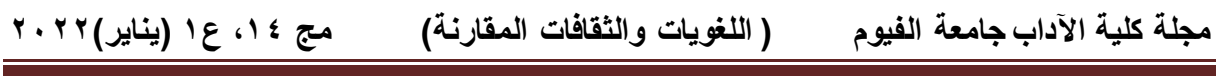

and discussion, trying to understand the identity of the other in all interconnected societies, especially at a time when digital media have brought closer opportunities for communication and direct interaction and correcting insights that are not clear to the whole world. So, a so-called dialogue of civilizations emerged in search of a safe social life for all. The change in the policy of the United States, represented in the language of cultural dialogue in Disney films, reflects its clear goal of preserving the international position as the only dominant power in the world, without competition from anyone. Consequently, more studies are recommended to be conducted about the film and its different effects on different sides of both societies. More deep analysis is required to get cultures closer and more understanding toward each other. Other studies about subtitling can be conducted for gaining knowledge about differences in previous and current ones.

("Aladdin" in the Eyes of Disney 2019...) Dr. Yousreya Ahmed Alhamshary 


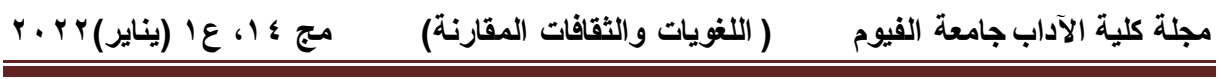

\section{References}

Adler, N. (1997) International Dimensions of Organizational Behavior.

3rd ed. Ohio: South-Western College Publishing.

Avruch, K. (1998) Culture and Conflict Resolution. Washington DC: United States Institute of Peace Press.

Belkhyr, S. (2013) 'Disney Animation: Global Diffusion and Local Appropriation of Culture', Études Caribéennes, 22, 15-22.

Benhamou, N. (2014) From the Advent of Multiculturalism to the Erasure of Race: The Representation of Race Relations in Disney Animated Features (1995- 2009). Exchanges: the Warwick Research Journal, Vol. 2(1), October 2014

Berry, G. (2003) Developing Children and Multicultural Attitudes: The Systematic Psychosocial Influences of Television Portrayals in a Multimedia Society. Available through: PsycARTICLES.

Collier-Meek, M.; Descartes, L. \& England, D. (2011) Gender Role Portrayal and the Disney Princesses. Sex Roles 64, 555-567.

Edmondson, J. (2013). Music in American Life: An Encyclopedia of the Songs, Styles, Stars, and Stories that Shaped our Culture. The United States of America: Greenwood.

Fairclough, N. (2003). Analyzing Discourse: Textual Analysis for Social Research. London: Routledge.

Gardels, N. \& Medavoy, M. (2009). American Idol after Iraq: Competing for Hearts and Minds in the Global Media Age. UK: Wiley-Blackwell

Giroux, H. (1995) 'The Disneyfication of Children's Culture', Socialist Review, 24, 23-55.

Gutner, B. (1995) Television and Gender Representation. London: John Libbey \& Company Ltd.

Hall, S. (1997). Representation Cultural Representations and Signifying Practice. USA: The Open University. Sage Publication.Ltd.

Hazell, V \& Clarke, J. (2008) "Race and Gender in the Media: A Content Analysis of Advertisements in Two Mainstream Black Magazines". Journal of Black Studies. 39.1: 5-21.

("Aladdin" in the Eyes of Disney 2019...) Dr. Yousreya Ahmed Alhamshary 


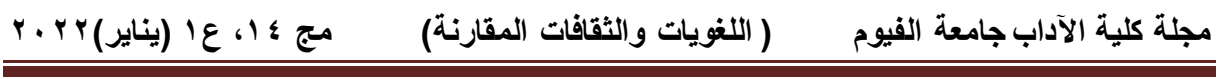

Hedenmalm, L. (2012) Language and Gender in Disney A Study of Male and Female Language in Walt Disney Movies. A published thesis in Luleå University of Technology

Hischak , T. \& Robinson, M.(2009) The Disney Song Encyclopedia. Scarecrow Press.

Hofstede, G. (2001) Culture's Consequences. Comparing Values, Behaviors, Institutions, and Organizations across Nations. 2nd ed. London: Sage.

Hudson, R. (1980). Sociolinguistics. Cambridge: Cambridge University Press

Kellner, D., \& Durham, M. (2001). Media and Cultural Studies: Keywords. Malden: Blackwell Publishers

Kress, G. \& Van Leeuwen, T. (1996). Reading Images: The Grammar of Visual Design. London: Routledge

Kress, G. \& Van Leeuwen, T (2006) Reading Images: The Grammar of Visual Design. London: Routledge.

LaCroix, C. (2004)" Images of Animated Others: The Orientalization of Disney's Cartoon Heroines from the Little Mermaid to The Hunchback of Notre Dame". Popular Communication. 2.4: 213-229.

Lustig, M. \& Koester, J. (1999) Intercultural Competence. Interpersonal Communication across Cultures. 3rd ed. New York: Longman

Martin, J. \& Ostwalt, C. (1995) Screening The Sacred: Religion, Myth, And Ideology In Popular American Film. Westview Press; 1 edition (March 30, 1995)

Matsumoto, D. (1996) Culture and Psychology. Pacific Grove, CA: Brooks/Cole

Miles, M. (1996). Seeing and Believing: Religion and Values in the Movies. Boston: Beacon Press.

Morawitz, E \& Mastro, D. (2008) "Mean Girls? The Influence of Gender Portrayals in Teen Movies on Emerging Adults' Gender-Based Attitudes and Beliefs". Journalism and Mass Communication Quarterly. 85.1: 131-146.

("Aladdin" in the Eyes of Disney 2019...) Dr. Yousreya Ahmed Alhamshary 


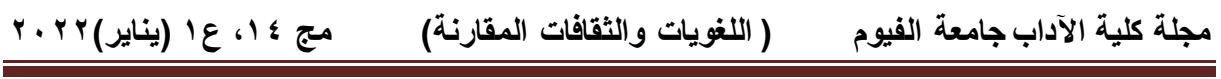

Pinsky, M (2004) The Gospel According to Disney: Faith, Trust, and Pixie Dust. Louisville, KY: Westminster John Knox Press.

Rahayu, M. \& Abdullah, I. \& Udasmoro, W. (2015) "Aladdin" from Arabian Nights to Disney: The Change of Discourse and Ideology. LiNGUA Vol. 10, No. 1, Juni 2015 • ISSN 1693$4725 \cdot$ e-ISSN 2442-3823

Said, E. (1978) Orientalism, New York City: Pantheon Books.

Shohat, E. (1990). Gender in Hollywood's Orient. Middle East Report No. 162, Jan. - Feb. 1990, pp. 40-42.

Spencer-Oatey, H. (2008) Culturally Speaking. Culture, Communication and Politeness Theory. 2nd Edition. London: Continuum

Spencer-Oatey, H. (2012) What Is Culture? A Compilation of Quotations.

URI http://www.warwick.ac.uk/globalpadintercultural

Thussu, D. (2006) International Communication: Continuity and Change, London: Bloomsbury Academic.

Totman, S. (2009). How Hollywood Projects Foreign Policy. New York: Palgrave Macmillan.

Van Dam, B. (2014) Disney's Fashionable Girls: Signs and Symbols in the Costume Dress of Disney's Female Characters. A published thesis by Stockholms Universitet, Centrum för modevetenskap

Walsh-Childers, K. (2003)"Women as Sex Partners." Images the Injure. Ed. Paul Martin Lester \& Susan Dente Ross. Westport: Praeger Publishers. 141-148.

Witt, S. (2000) The Influence of Television on Children's Gender Role Socialization. Childhood Education 76 (5), 322-324.

Young, L. (1996). Fear of the 'Dark' Race: Race, Gender and Sexuality in the Cinema. London: Routledge

Zitawi, J. (2008) Contextualizing Disney Comics within the Arab Culture. The Verbal, the Visual, the Translator Vol 53(1).

URI: https://id.erudit.org/iderudit/017979ar DOI : https://doi.org/10.7202/017979ar

("Aladdin" in the Eyes of Disney 2019...) Dr. Yousreya Ahmed Alhamshary 


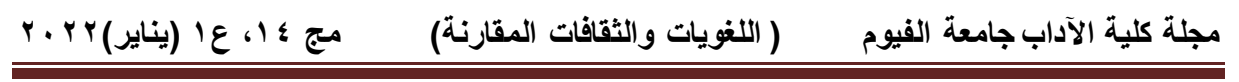

\section{Popular sources}

Aladdin. Director Rob Clements and John Musker. The Walt Disney Company. 1992.

URL: $\quad$ https://www.cartoonbrew.com/disney/john-musker-co-directoraladdin-moana-retires-disney-40-years-157319.html

URL: https://www.youtube.com/watch? $\mathrm{v}=$ gbnleaMdwXw

("Aladdin" in the Eyes of Disney 2019...) Dr. Yousreya Ahmed Alhamshary 